\title{
Cerrahi Yoğun Bakım Hastalarında Kontrast Madde Nefropatisi için Risk Faktörleri
}

\author{
Risk Factors For Contrast Induced Nephropathy in Surgical Intensive \\ Care Unit Patients
}

\author{
Coşkun Araz, Hakan Musa Ayas, Aynur Camkıran, Arash Pirat, Pınar Zeyneloğlu, Gülnaz Arslan \\ Baskent Üniversitesi Tıp Fakültesi, Anesteziyoloji Anabilim Dalı, Ankara, Türkiye
}

\section{ÖZET}

Amaç: Çalışmamızda, cerrahi yoğun bakım hastalarında kontrast madde kullanılmasına bağlı oluşabilen böbrek hasarı (CIN, Contrast Induced Nephropathy) sıklığı ve gelişimi için risk faktörlerini değerlendirmeyi amaçladık.

Gereç ve Yöntem: Ocak 2001-Eylül 2006 arasında hastanemiz yoğun bakımına kabul edilen hastaların dosyaları retrospektif olarak incelendi ve kontrast madde kullanılmıs hastalar çalıșmaya dahil edildi. Kontrast madde $(\mathrm{KM})$ verildiği dönemde renal replasman tedavisi almakta olan hastalar çalışma dışı bırakıldı. Hastalar $\mathrm{CIN}$ gelişen $(\mathrm{CIN}(+))$ ve gelișmeyenler (CIN(-) olmak üzere iki gruba ayrıldı. CIN gelișimi için serum kreatinin seviyelerinin, KM'ye maruz kalma sonrası ilk 72 saat içerisinde bazal değerden $0,5 \mathrm{mg} / \mathrm{dL}$ veya \%25 fazla olması kriter olarak kabul edildi. Bulgular: Belirtilen kriterler çerçevesinde kontrast madde kullanılan toplam 42 hastanın 17'sinde CIN gelişti. Gruplar demografik verileri, APACHE II skorları ve yoğun bakıma alınma nedenleri bakımından benzer bulundu. $\mathrm{CIN} \mathrm{(+)} \mathrm{grubunda} \mathrm{konjestif} \mathrm{kalp} \mathrm{yetmezliği} \mathrm{CIN(-)} \mathrm{grubundan}$ daha fazla bulundu $\left(\% 35^{\prime} \mathrm{e}\right.$ karşın $\left.\% 8, p=0,045\right)$. CIN $(+)$ grubunda, KM'ye maruz kalma öncesindeki hemoglobin düzeyi, KM'ye maruz kalma sonrasındaki parsiyel arteriyel oksijen basınçları ve diyastolik kan basınc CIN(-) grubuna göre istatistiksel olarak anlamlı olarak düşük bulundu

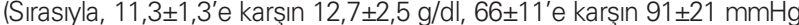
ve $59 \pm 17$ 'ye karşın $72 \pm 19 \mathrm{mmHg}$, tüm değerler için $p<0,05$ ). Elde edilen parametrelerin çok değişkenli lojistik regresyon modelinde incelenmesiyle yalnızca arteriyel oksijen basıncının CIN gelișimi için bağımsız bir risk faktörü olduğu gözlendi (OR:0,842; $\mathrm{Cl}=0,75-0,95 ; \mathrm{p}=0,005)$.

Sonuç: Düşük arteriyel oksijen basıncı seviyeleri yoğun bakım hastalarında CIN gelişimi için bir risk faktörüdür. Oksijenlenmeyi artırmaya yönelik alınacak önlemler ile yoğun bakım hastalarında CIN gelişiminin azaltılabileceğini düşünüyoruz. (Türk Yoğun Bakım Derneği Dergisi 2012; 10: 1-7)

Anahtar Kelimeler: Yoğun bakım, kontrast madde nefropatisi, risk

\section{SUMMARY}

Objective: The aim of this study was to evaluate the risk factors for the development of contrast induced nephropathy $(\mathrm{CIN})$ in surgical intensive care unit (ICU) patients.

Material and Method: The charts of the patients who were admitted to the ICU between January 2001 and September 2006 were reviewed. Those patients who were exposed to contrast media (CM) during their ICU stay were included. Patients who were receiving renal replacement therapy at the time of CM exposure were excluded. Patients were divided into two groups based on whether they developed $\mathrm{CIN}(\mathrm{CIN}(+))$ or not (CIN(-). CIN was defined as an increase in serum creatinine values of $\geq 0.5 \mathrm{mg} / \mathrm{dl}$ or a $\geq 25 \%$ increase from baseline within 72 hours after administration of contrast agent. Results: Of 42 patients who were included in the study 17 fulfilled the criteria of CIN. There was no statistically significant difference between Group $\mathrm{CIN}(+)(n=17)$ and Group $\mathrm{CIN}(-)(\mathrm{n}=25)$ in terms of demographic features, APACHE II scores, and reasons for ICU admission. Patients in group $\mathrm{CIN}(+)$ had a significantly higher rate of congestive heart failure than those in Group (CIN(-) (35\% vs 8\%, $\mathrm{p}=0.045)$. Compared with Group ( $\mathrm{CIN}(-)$, hemoglobin level before $\mathrm{CM}$ exposure as well as partial arterial oxygen pressure and diastolic blood pressure after $\mathrm{CM}$ exposure were significantly lower in Group $(\mathrm{CIN}(+)(12.7 \pm 2.5$ vs $11.1 \pm 1.3 \mathrm{~g} / \mathrm{dl}, 91 \pm 21$ vs $66 \pm 11 \mathrm{mmHg}$, and $59 \pm 17$ vs $72 \pm 19 \mathrm{mmHg}$, respectively). Multivariate logistic regression revealed that only partial arterial oxygen pressure was significantly associated with $\mathrm{CIN}$ (OR:0.842; $\mathrm{Cl}=0.75-0.95 ; \mathrm{p}=0.005$ ).

Conclusion: Our results indicate that a low arterial oxygen pressure is a risk factor for development of CIN in ICU patients. Measures to improve oxygenation may reduce the risk of this complication in ICU patients. (Journal of the Turkish Society Intensive Care 2012; 10: 1-7) Key Words: Intensive care, contrast induced nephropathy, risk

Yazışma Adresi/Address for Correspondence: Dr. Coşkun Araz, Baskent Üniversitesi Tıp Fakültesi, Anesteziyoloji Anabilim Dalı, Ankara, Türkiye Tel.: +90 3122126868 Faks: +90 3122237333 E-posta: arazcoskun@yahoo.com Geliş Tarihi/Received: 12.10.2011 Kabul Tarihi/Accepted: 10.01.2012 


\section{Giriş}

Hastanede takip edilmekte olan hastalarda çok çeşitli sebeplere bağlı olarak gelişebilen akut böbrek yetmezliği, hem morbidite ve mortaliteyi arttırması, hem de maliyet üzerine olan olumsuz etkileri nedeniyle önemli bir sorundur (1-4). Bu edinsel yetmezlik, böbreğin perfüzyonunun bozulması ya da nefrotoksik ajanlara maruz kalmakla oluşan nefron hasarına bağlı olarak gelişir. Yoğun bakım hastaları, bozulmuş hemodinamik profilleri, mekanik ventilasyon uygulanması, fazla sayıda ilaç kullanma gereksinimleri, bozulmuş Sıvı ve elektrolit dengeleri ya da ek sistemik hastalıkların fazlalığı gibi nedenlerden dolayı akut böbrek yetmezliği gelişimi için yüksek riskli hastalardır (5-7). Anestezi, cerrahi ve teknolojik alanlardaki ilerlemeler sayesinde, tıbbi açıdan daha ağır ve ileri yaşı hastalar cerrahi için kabul edilebilmekte, cerrahi yoğun bakımlara alınan hastaların yaş ortalamaları ve ilişkili olarak ek sistemik hastalıkların bulunma oranları zamanla artmaktadır (1,2,8-10). Bu hastaların değerlendirilmesinde primer veya sekonder nedenlerden dolayı bozulmuş mental durumları ya da fonksiyonel yanıtsızlıklarına bağlı olarak fizik muayene için uygun olmayışları sebebiyle radyolojik görüntüleme yöntemlerinin önemli bir yeri vardır. Kontrast maddeler (KM), görüntüleme yöntemleri kullanılırken daha kaliteli görüntü elde edebilmek veya fonksiyonel görüntü oluşturabilmek amacıyla sıklıkla kullanılır $(1,2,11)$.

Son on yıllık dönemde KM kullanarak görüntüleme yapılmasında dramatik bir artış olmuştur. Hastalarda KM kullanılması genellikle güvenli bir yöntemdir, ancak yatkınlığı bulunan kişilerde allerjik reaksiyonlar ve KM'ye bağlı oluşabilen böbrek hasarı (CIN, Contrast Induced Nephropathy) gibi bazı istenmeyen durumlarla karşılaşılabilmektedir (2). Literatürde CIN insidansı \%2'den $\% 50$ 'lere varan oranlarda bildirilmiştir $(2,12,13)$. Günümüzde daha az toksik özellikteki, düşük yoğunluklu, non-iyonik yapılı KM'lerin kullanılmasının artması ve profilaktik koruyucu yöntemlerin yaygınlaşmasıyla CIN gelişme insidansında belirgin bir azalma göze çarpmaktadır. CIN gelişen hastalardaki hasar genellikle geçicidir. Ancak kronik kompanse böbrek hastalığı, küçük damar hastalığı ve/veya diyabetes mellitusu bulunan hastalarda kalıcı, son dönem böbrek yetmezliğine kadar ilerleyen tablolara rastlanabilir $(2,4,12,14,15)$. Ileri yaş, konjestif kalp yetmezliği, nefrotoksik ilaç kullanımı, hipovolemi, fazla miktarda KM kullanılması, prediyabet, hipertrigliseridemi ve hiperürisemi de diğer risk faktörleri olarak bildirilmiştir $(1,2,12,13,16)$.

KM'ler, gerek içerdikleri elementler, gerekse yoğunlukları nedeniyle yüksek nefrotoksisite potansiyeli olan maddelerdir $(16,17)$. Bu nedenle, yüksek nefrotoksisite potansiyeli bulunan yoğun bakım hastalarında kullanılmaları ayrı bir klinik özellik arz eder. CIN gelişimi, kullanılan KM'nin türüne, miktarına, yoğunluğuna, maruz kalma süresine ve sayısına, ayrıca hastanın renal ve diğer organ fonksiyonlarının yeterliliğine ve KM maruziyeti öncesi ve sonrası uygulanan tıbbi destek yöntemlerinin yeterliliği gibi faktörlere bağlı olduğu düşünülmektedir $(1,16)$. Ancak KM'ye maruz kaldıktan sonra CIN gelişimi ile ilgili yoğun bakım hastalarında az sayıda çalışma mevcuttur.

Bu çalışmada, hastanemiz cerrahi yoğun bakım hastalarında kontrast madde kullanımı sonrasında gelişen nefropatinin sıklığı ve risk faktörlerini belirlemeyi amaçladık.

\section{Gereç ve Yöntem}

Hastanemiz Klinik Araştırma ve Etik Kurulları onayı alındıktan sonra (KA06/214), Ocak 2001- Eylül 2006 tarihleri arasında hastanemiz 6 yataklı cerrahi yoğun bakım ünitesine kabul edilmiş olan hastaların dosyaları ve bilgisayar kayıtları retrospektif olarak incelenerek herhangi bir nedenle intravenöz yoldan KM maruziyeti olan hastalar belirlendi. Hastaların demografik verileri, yandaş hastalıkları, kullanmakta oldukları ilaçlar, pozitif inotropi ve/veya vazodilatör intiyaçları, kristalloid, kolloid, kan ve diğer kan ürünlerinin gereksinimleri, idrar çıkışları, diüretik kullanımları, mekanik ventilasyon ihtiyaçları ve uygulanma süreleri, APACHE II skorları, yoğun bakıma alınma nedenleri, laboratuar ve kan gazı değerleri, hemodinamik verileri, hastane ve yoğun bakım kalış süreleri ve mortaliteleri kaydedildi. Aminoglikozid grubu antibiyotikler, vankomisin, amfoterisin B, steroid yapıda olmayan antiinflamatuar ilaçlar ve ACE inhibitörleri gibi nefrotoksik yapıda olan ilaçların kontrast madde maruziyeti ile eş zamanlı kullanılmaları not edildi. Bu hastalardan, arteriyel kontrast madde verilenler, son dönem böbrek yetmezliği hastası olanlar, KM maruziyeti anında böbrek yetmezliği nedeniyle renal replasman tedavisi almakta olanlar, KM verilmeden önceki 48 saatlik dönemde serum kreatinin düzeyinde $0,5 \mathrm{mg} / \mathrm{dL}$ artış olanlar ve sadece oral yoldan KM alan hastalar çalışma dışı bırakıldı. KM verilmesi planlanan hastalara rutin olarak $10 \mathrm{~mL} / \mathrm{kg}$ kristalloid sıvı ve 20 $\mathrm{mg} / \mathrm{kg} \mathrm{N}$-asetil sistein (NAC, Asist ${ }^{\circledR}$ ) IV yoldan 1 saat içerisinde verildi. Diğer profilaktik koruma yöntemleri kullanılmadı. Tüm hastalarda standart olarak $100 \mathrm{~mL}$, noniyonik yapıda KM (lohexol, (Omnipaque $\left.{ }^{\circledR}\right)$ ) kullanıldı. Hastalar, CIN gelişme durumuna göre iki grup halinde (Grup CIN(+) ve Grup CIN(-)) gruplandırıldı. Hastaların, KM maruziyeti öncesi ve sonrasında günlük olarak kreatinin değerleri kaydedildi. Hiçbir hastada 24 saatlik idrarda kreatinin klirensi hesaplanmadı. CIN gelişimi için serum kreatinin seviyelerinin, KM maruziyeti sonrası ilk 72 saat içerisinde bazal değerden 0,5 mg/dL veya \%25 fazla olması kriter olarak kabul edildi. KM maruziyeti sonrasında oligüri, ciddi metabolik asidoz, hiperkalemi ya da hipervolemi bulunması durumunda renal replasman tedavisi (RRT) uygulandı. Hastaların RRT gereksinimleri ve mortaliteler kaydedildi. 
Mekanik ventilasyon uygulanan yoğun bakım hastalarımızda akciğer koruyucu ventilasyon stratejleri uygulamaktayız $(6 \mathrm{~mL} /$ ideal vücut ağılığı, düşük basınç Phigh< $30 \mathrm{cmH}_{2} \mathrm{O}$, normal $\mathrm{pH}$ ve normokapninin sağlanması ve arteriyel oksijen satürasyonu >92 olacak şekilde $\mathrm{FiO}_{2}{ }^{\prime}$ nin $<\% 50$ olması, gibi). Bu hastaların görüntüleme için transferi sırasında taşınabilir otomatik ventilatör kullanılmakta ve benzer stratejilere bu dönemde de devam edilmektedir. Yoğun bakımda bulunan hastalarda kan gazı örneklemeleri, hastaların klinik durumları göz önüne alınarak yapılmaktadır. Görüntüleme yöntemleri için transportu yapılan hastaların kan gazı değerlendirmeleri gerekli bir durum olmadıkça (hemodinamik instabilite, solunum sıkıntısı gibi), hastalar işlem sonrasında geri dönüp ventilatör desteğine tekrar adapte olduktan sonra, yani işlemden (kontrast madde verilmesinden) yaklaşık en az 1 saat kadar sonra alınmaktadır. Çalışmamızda, değerlendirdiğimiz hastaların verilerinin de belirtilen özelliklerde olduğu gözlendi.

Istatistiksel analizler, Windows için yapılmış SPSS 17,0 programıla (SPSS Inc. Chicago IL) yapıldı. Gruplar arası karşılaştırmada Mann Whitney-U testi, grup içi ölçüm zamanlarını karşılaştırmada Friedman ve Wilcoxon testleri, oranların karşılaştıııması için de Ki-kare testi kullanıldı. Klinik ve istatistiksel olarak anlamlılık gösteren değişkenler ile, nefropati gelişmesi için risk faktörlerini belirleyebilmek amacıyla lojistik regresyon analizi yapıldı. Veriler ortalama \pm standart sapma (Standard Deviation, SD) olarak sunuldu. $p<0,05$ değerleri istatistiksel olarak anlamlı kabul edildi.

\section{Bulgular}

Ocak 2001-Eylül 2006 tarihleri arasında hastanemiz cerrahi yoğun bakım ünitesine toplam 796 hasta kabul edildi. Bu hastaların 64'ünde $(\% 8,0)$ IV yoldan KM kullanılarak görüntüleme yapılması gerekli oldu. Bu hastalardan 42 'sinde $(\% 5,3)$ belirtilen kriterlere uyan KM maruziyeti tespit edildi ve bunların 17'sinde $(\% 2,1) \mathrm{CIN}$ gelişimi gözlendi. Grupların demografik verileri, APACHE ॥ skorları, yoğun bakıma alınma nedenleri, kalp yetmezliği haricinde diğer sistemik hastalıkları, yoğun bakım ve hastane kalış süreleri istatistiksel olarak benzerdi (Tablo 1).

Grupların KM maruziyeti öncesi laboratuvar değerleri, hemodinamik verileri, mekanik ventilasyon, vazokonstriktör ve renal replasman tedavisi gereksinimleri, kontrast madde maruziyeti öncesi ve sonrası kan gazları ve mortaliteleri karşılaştırılı. Kontrast madde verilmesi planlanan hastalarda nefrotoksik potansiyeli olan ilaçlar (NSAI ilaçlar hariç) hemen kesilmedi. NSAI ilaçların ise bu hastalara kontrast madde kullanılması sonrasında ilk 24 saat hiç kullanımadığı gözlendi. Bu ilaçları kullanan hastalar çalışma dışı bırakılmadı. Fakat hastaların tüm nefrotoksik ilaç kullanımları kaydedildi (Tablo 2).

"Konjestif kalp yetmezliği olan hasta sayısı Grup CIN $(+)^{\prime}$ te, Grup CIN (-)'e oranla anlamlı şekilde daha fazla bulundu ( $n=6,(\% 35)^{\prime}$ e karşın $\left.n=2,(\% 8), p=0,045\right)$. Ayrıca, Grup CIN (+) ve Grup CIN (-) arasında KM maruziyeti

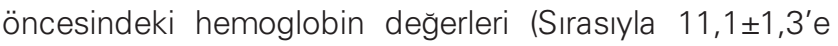
karşın $12,7 \pm 2,5 \mathrm{~g} / \mathrm{dl}, \quad \mathrm{p}=0,010), \quad \mathrm{KM}$ maruziyeti

Tablo 1. Tanımlayıcı veriler ve yoğun bakım verileri

\begin{tabular}{lccc} 
& Grup CIN (+) (n=17) & Grup CIN (-) (n=25) & p \\
\hline Yaş (yıl) & $69,8 \pm 9,6$ & $63,2 \pm 19,1$ & 0,222 \\
Cinsiyet (K/E) & $11 / 6$ & $11 / 14$ & 0,475 \\
APACHE II Skoru & $19,6 \pm 6,1$ & $21,6 \pm 10,3$ & 1,000 \\
Yoğun bakıma alınma sebebi & & & 0,353 \\
Solunumsal nedenler & $7 / 17$ & $11 / 25$ & 0,786 \\
Postoperatif izlem & $8 / 17$ & $8 / 25$ & \\
Diğer & $2 / 17$ & $6 / 25$ & 0,066 \\
Sistemik Hastalıkları & & & 0,086 \\
Hipertansiyon & $12 / 17$ & $10 / 25$ & 0,660 \\
Diyabetes Mellitus & $7 / 17$ & $4 / 25$ & 0,305 \\
Malignite & $6 / 17$ & $6 / 25$ & 0,045 \\
Koroner arter hastalığı & $5 / 17$ & 0,983 \\
Kalp yetmezliği & $6 / 17$ & $2 / 25$ & \\
Yoğun bakım kalış süresi (gün) & $24,5 \pm 24,0$ & \\
\end{tabular}


sonrasındaki pO2 düzeyleri $(65,6 \pm 15,0$ 'e karşın $91,1 \pm 30,8$ $\mathrm{mmHg}, p=0,027)$ ve diyastolik kan basıncı seviyeleri $(59 \pm 17$ 'e karşın $72 \pm 19 \mathrm{mmHg}, p=0,036)$ istatistiksel olarak anlamlı şekilde farklı bulundu. Elde edilen parametrelerin çok değişkenli lojistik regresyon modelinde incelenmesiyle yalnızca pO2'nin bağımsız bir risk faktörü olduğu gözlendi (Tablo 3).

\section{Tartışma}

Cerrahi yoğun bakım hastalarında, KM kullanılmasına bağlı gelişebilen nefropati için risk faktörlerini incelediğimiz çalışmamızda, KM kullanııması sonrasında nefropati gelişen hastalarda konjestif kalp yetmezliğinin daha fazla olduğu görüldü. Ayrıca nefropati gelişen hastalar, nefropati

Tablo 2. işlem öncesi laboratuar değerleri, hemodinamik veriler, kontrast madde verilmesi sonrası kan gazı verileri ve diğer veriler

\begin{tabular}{|c|c|c|c|}
\hline & Grup CIN (+) (n=17) & Grup CIN (-) $(n=25)$ & $\mathbf{p}$ \\
\hline \multicolumn{4}{|l|}{ Işlem öncesi laboratuvar değerleri } \\
\hline Hemoglobin (g/dL) & $11,1 \pm 1,3$ & $12,7 \pm 2,5$ & 0,010 \\
\hline Lökosit (bin/ $\mu \mathrm{L})$ & $11,2 \pm 4,8$ & $12,9 \pm 8,3$ & 0,456 \\
\hline Trombosit (K//ML) & $200 \pm 80$ & $236 \pm 108$ & 0,251 \\
\hline Albumin $(\mathrm{g} / \mathrm{dL})$ & $1,30 \pm 0,98$ & $3,46 \pm 0,83$ & 0,168 \\
\hline Kreatinin (mg/dL) & $3,04 \pm 0,54$ & $1,32 \pm 1,16$ & 0,955 \\
\hline AST (U/L) & $56,0 \pm 46,4$ & $47,1 \pm 46,5$ & 0,968 \\
\hline ALT (U/L) & $38,6 \pm 28,9$ & $36,0 \pm 44,4$ & 0,767 \\
\hline \multicolumn{4}{|l|}{ Hemodinamik değerler } \\
\hline Sistolik Kan Basıncı (mmHg) & $128 \pm 24$ & $135 \pm 42$ & 0,537 \\
\hline Diyastolik kan basıncı (mmHg) & $72 \pm 17$ & $70 \pm 17$ & 0,705 \\
\hline Ortalama kan basıncı (mmHg) & $89 \pm 21$ & $93 \pm 17$ & 0,548 \\
\hline Kalp atım hızı (atım/dak) & $108 \pm 16$ & $97 \pm 25$ & 0,125 \\
\hline Santral venöz basınç (mmHg) & $8,73 \pm 4,56$ & $9,23 \pm 3,53$ & 0,713 \\
\hline \multicolumn{4}{|l|}{ KM Sonrası Kan Gazı Değerleri } \\
\hline ph & $7,412 \pm 0,091$ & $7,43 \pm 0,048$ & 0,394 \\
\hline $\mathrm{pCO}_{2}(\mathrm{mmHg})$ & $41,2 \pm 13,3$ & $42,5 \pm 24,4$ & 0,878 \\
\hline Arteriyel oksijen basıncı & $65,6 \pm 15,0$ & $91,1 \pm 30,8$ & 0,027 \\
\hline (mmHg) (İşlem öncesi) & . & . & . \\
\hline Arteriyel oksijen basıncı & $80,3 \pm 23,0$ & $83,2 \pm 13,4$ & 0,739 \\
\hline (mmHg) (işslem öncesi) & . & . & \\
\hline Bikarbonat değeri & $24,6 \pm 8,3$ & $24,3 \pm 4,2$ & 0,930 \\
\hline Mekanik ventilasyon ihtiyacı (n) & $3 / 17$ & $7 / 25$ & 0,439 \\
\hline Vazokonstriktör ihtiyacı (n) & $3 / 17$ & $7 / 25$ & 0,439 \\
\hline Nefrotoksik ilaç kullanımı (n) & $8 / 17$ & $8 / 25$ & 0,324 \\
\hline Mortalite (n) & $14 / 17$ & $20 / 25$ & 0,849 \\
\hline RRT gerekli olanlar (n) & $7 / 17$ & $9 / 25$ & 0,735 \\
\hline
\end{tabular}

\section{Tablo 3. Tablo 1 ve 2 de verilen değerlerle yapılan lojistik regresyon analizleri}

\begin{tabular}{lccc} 
& OR & Cl (\%5 - \%95) & p \\
\hline Hipertansiyon & 0,843 & $0,09-7,20$ & 0,84 \\
Diyabetes mellitus & 0,644 & $0,50-8,91$ & 0,74 \\
Kalp yetmezliği & 0,064 & $0,00-2,73$ & 0,15 \\
Hemoglobin (gr/dL)* & 1,068 & $0,49-2,32$ & 0,87 \\
Diyastolik kan basıncl $(\mathrm{mmHg})^{* *}$ & 0,937 & $0,86-1,02$ & 0,14 \\
$\mathrm{PaO}_{2}(\mathrm{mmHg})^{* *}$ & 0,842 & $0,75-0,95$ & 0,005 \\
\hline
\end{tabular}

*: KM'ye maruz kalma öncesindeki değerler, **: KM'ye maruz kalma sonrasındaki değerler 
gelişmeyen hastalarla karşılaştırıldığında KM maruziyeti öncesindeki hemoglobin seviyeleri ve KM maruziyeti sonrasındaki arteriyel oksijen basıncı ve diyastolik kan basınçları anlamlı olarak düşüktü. Ancak değerler analiz edildiğinde yalnızca arteriyel oksijen basıncının CIN gelişiminde bağımsız bir risk faktörü olduğu belirlendi.

Yoğun bakım hastalarında CIN gelişimi hakkındaki veriler oldukça kısıtıdır. Literatürde yoğun bakım hastalarında CIN insidansı \%2-50 arasında bildirilmiştir $(2,3,18)$. Insidansın bu kadar farklı yüzdelerde belirtilmesinin sebebi, CIN gelişiminin birden fazla nedene bağlı olması olarak gösterilmiş ve yapılan çalışmalarda bu konulara dikkat çekilmiştir. Özellikle kronik böbrek hastalığı, diyabeti ve kalp yetmezliği bulunan hastalarda CIN gelișimi için artmıș bir risk oranı literatürde dikkat çekmektedir. Bizim çalışmamızda, CIN oranı \%40 olarak gözlendi. Bu yüksek oranı, hastaların sistemik hastalıklarının birden fazla ve ağır olmasına bağlıyoruz. Ayrıca yoğun bakımımızda yardımcı tanısal yöntemler gerekli olduğunda öncelikli tercihimizi, yatak başı uygulanabilen ve kontrast madde kullanıması gerekli olmayan ultrasonografi gibi tekniklerden yana yapıp, kontrast madde kullanılması gerekli olabileceğini düşündüğümüz tetkikleri mümkün olduğunca son tercih olarak kullanmaktayız.

KM maruziyetine bağlı gelişen böbrek foksiyon bozukluğu önlenebilir ve geri döndürülebilir bir durumdur $(1,2)$. Yoğun bakım hastaları, multifaktöriyel olarak böbrek yetmezliği gelişimi açısından risk altında bulunurlar (3). Böbrek yetmezliğinin oluşması, sıklıkla böbrek perfüzyonunda oluşan bozulma ya da nefrotoksik ajanların kullanılması sonucunda gelişir. Bu hastalarda gelişen böbrek yetmezliği ile morbidite, mortalite ve hastane maliyeti artar $(3,19)$. KM verilmesi sonrasında adenozin, endotelin ve prostaglandin salınmasındaki değişikliklerle renal arterlerde vazokonstriksiyon gelişir. Bu da, meduller hipoksemi ve iskemi nedenli oksidatif stres oluşmasını tetikler. KM'lerle uzun süreli olan temas, tubüler hücreler için toksiktir ve hücre ölümüne neden olur (3,19-22). Çalışmamız sırasında incelediğimiz hastalardan 42'sinin belirtilen kriterler çerçevesinde KM maruziyetinin olduğu gözlendi. Bu hastalardan 17'sinde (\%42) CIN gelişimi gözlenirken 25 'inde (\%58) tespit edilebilen bir böbrek hasarı gelişmedi. Ancak, çalışmamızda ki bu oranları yalnızca KM kullanımı ile ilişkilendirmek doğru olmayabilir. Benzer çalışmalarda da görüldüğü gibi bizim çalışmamızda da hastaların klinik durumları, böbrek hasarı için predispozisyon oluşturabilecek var olan hastalıkları ve nefrotoksisite riski oluşturabilecek diğer nedenlerde hastaların böbrek yetmezliği gelişmesinde rol oynar.

Kontrast madde kullanımına bağlı gelişen nefropatinin patofizyolojisinde hipoksi, kontrast madde toksisitesi ile birlikte rol oynar. Oluşan hipoksi nedeniyle ortamda artan serbest oksijen radikalleri de bu duruma katkıda bulunur $(23,24)$. Brezis ve ark. yüksek osmolariteli kontrast madde kullanımı ile renal kortikal arteriyel oksijen basıncının anlamlı şekilde düştüğünü bildirmişlerdir (25). Diğer bir çalışmada ise (26), hipoksi ile indüklenebilen faktörlerin inhibe edilmesi ile, transplant ve iskemik böbreklerin korunabilirliğinin artırılabileceği bildirilmiştir. Hofmann ve ark'nın çalışmasında ise, ilaç nedenli böbrek yetmezliğinde de hipoksinin anahtar rol üstlendiğine dikkat çekilmiştir (27). Çalışmamızda işlem öncesi ve sonrasında alınmış olan kan gazları incelendiğinde işlem sonrasında ki arteriyel oksijen basıncının CIN gelişen hastalarda anlamlı şekilde düşük olduğu gözlendi. Fakat CIN gelișiminde, mevcut olan hipoksinin KM eklenmesi ile daha da derinleșeceği kanaatindeyiz. Bu nedenle, hem KM verilmeden önce hem de KM verildikten sonra hastaların uygun doku perfüzyonu ve oksijenasyonunun sağlanmasının önemli olduğunu düşünüyoruz. Bunlara ek olarak doku oksijenasyonunu sağlamada hemoglobin seviyelerinin normal sınırlarda olmasının sağlanması kritik önem taşır. Uygun hemoglobin seviyeleri oksijenasyonu iyileştirerek oluşabilecek hasarı engelleyebeilir. Hofmann ve ark. sağliklı gönüllülerde yaptıkları bir çalışmada, nefrotoksik ajan kullanılması ile renal doku oksijenasyonunda akut değişiklikler olduğunu bildirmişlerdir (27). Caruso ve ark. (28) var olan aneminin perkütan kardiyak girişimler sonrasında gelişen CIN'de etkin bir faktör olduğunu bildirmişlerdir. Çalışmamızda iki grup arasında KM'ye maruz kalma sırasındaki hemoglobin seviyelerinin anlamlı olarak farklı olmasına karşın, yapılan lojistik regresyon analizinde risk faktörü olarak saptanmadı.

KM'ye bağlı böbrek hasarı, başka bir neden olmaksızın KM kullanımı sonrasında 72 saatlik süre zarfında kreatinin seviyesinin $>0,5 \mathrm{mg} / \mathrm{dL}$ veya bazal serum kreatinin seviyesinin \%25 artması şeklinde tanımlanır $(1,2,4,20,21,29-32)$. KM kullanılması sonrasında gelişebilen böbrek fonksiyonlarındaki bozulma birden fazla sebebe bağlıdır. Bunlar, hastaya bağlı özellikler olabileceği gibi, KM'nin özelliklerine ya da hastanın almakta olduğu diğer tedaviler ve mevcut sağlık durumu gibi sebeplerle ilgili olabilir. Hipovolemi, anemi, diyabetes mellitus veya bozulmuş glukoz toleransı, var olan böbrek fonksiyon bozukluğu, hiperürisemi, metabolik sendrom, hipertrigliseridemi, 65 yaş üstünde olmak, kadın cinsiyet, konjestif kalp hastalığı olması, küçük damar hastalığı, ciddi sistolik disfonksiyon, eş zamanlı nefrotoksik ilaç kullanımı ve transplante böbrek hikayeleri CIN için hastaya ait risk faktörleri olarak bildirilmiştir. Kullanılan KM miktarı, KM yoğunluğu, iyot miktarı, yapılan işlemin uzunluğu, KM'nin intraarteriyel verilmesi ve 10 gün içinde tekrarlayan işlemler $\mathrm{CIN}$ gelişimin artıran diğer nedenlerdir (1-3,7,10,20-22,29-35). 
Türk Yoğun Bakım Derneği Dergisi / Journal of the Turkish Society of Intensive Care 2012;10:1-7

CIN'in önlenmesi için öncelikle CIN gelişme riskinin farkındalığı ön plandadır. Risk altındaki hastalarda KM maruziyeti öncesinde, hastaya ve/veya KM'ye ait risk faktörlerinin ortadan kaldırımaya çalışılması gerekir. Işlem öncesinde yapılacak sıvı yüklemesi, NAC ve alkalinizasyon tedavileri gibi uygulamalarla hastalarda CIN oluşumu azaltılabilir (1,2,4,7,18-20,22,29,30,32,35-37). Yüksek riskli hastalarda hemodiyaliz uygulamasıyla KM yükünü azaltmakta uygulanabilecek tedavi yöntemlerindendir. Biz KM kullanılacak olan hastalarımızda rutin olarak IV hidrasyon ve NAC uygulamaktayız. Ancak yüksek riskli olduğu düşünülen hastalarda (özellikle kronik böbrek hastalığı öyküsü bulunan ve diyabetli hastalarda) KM kullanılması halinde tek seferlik hemodiyaliz uygulayarak intravenöz KM yükünü azaltma uygulayıcının tercihine göre değişmekle beraber uygulanan yöntemlerdendir. Literatürde yer almasına rağmen profilaktik olarak teofilin ve/veya sodyum bikarbonat uygulamaları bizim rutin pratik uygulamalarımızda kullanılmamıştır.

Buna ek olarak yüksek riskli hastalarda işlem sonrasında da yapılabilecek destek tedavileri ile CIN oluşma intimalinin azaltılabilmesi mümkündür. Yine kullanılan KM'nin özelliklerinin değiştirilmesi de oluşabilecek nefrotoksisitenin azaltılmasına yardımcı olabilir $(1,2,4,7,18-20,22,29,30,32,35-37)$.

$\mathrm{Bu}$ amaçla hastaların işlem öncesi BUN ve kreatinin değerlerinin bilinmesi, 24 saatlik idrarda yapılan kreatinin klirensinin hesaplanması gibi yöntemler risk değerlendirmede yardımcı olabilir. Ancak son belirtilen yöntem pratik uygulamada kullanışlı olamayabilir. Bazı çalışmalarda bunun yerine Cockcroft-Gault formülü kullanılarak "tahmini glomerular filtrasyon hızının hesaplanmasınında" yararlı ve kullanışlı olabileceği gösterilmiştir. Sistatin $\mathrm{C}$ seviyesi, NGAL, IL-18 ve Glutatyon S transferaz gibi üzerinde durulan parametrelerinde $\mathrm{CIN}$ ön değerlendirmesinde ve takibinde kullanılabileceği bildirilmiştir $(1,7,20,35,38)$. Biz hastalarımızda rutin olarak günlük BUN ve kreatinin kontrolü yaptık. Kreatinin klirensi ya da tahmini glomerular filtrasyon hızı hesaplamasını rutin uygulamamızda kullanmamaktayız.

Kullanılan KM'lerin özellikleri de CIN gelişmesinde önemlidir. lyonik yapıdaki ve yüksek osmolaliteli (2000 mOsm/L) KM'lerin kullanımı yüksek nefrotoksik etkileri nedeniyle terk edilmiştir. Noniyonik ve düşük osmolaliteli KM kullanımı ile daha düşük oranda nefrotoksisite bildirilmiştir $(1,2,7,20,22,30,31,34)$. Bizim hastalarımızda noniyonik özellikteki düşük osmolaliteli KM'ler kullanıldı.

Nefropati gelişimi için yüksek risk altında bulunan hastalarda KM'ler yüksek nefrotoksik potansiyelleri ile bu riski daha da artırabilirler. Bu hastalarda KM'lere ek olarak nefrotoksik olan diğer farmakolojik ajanların kullanımı, son dönem böbrek hasarı oluşmasını kolaylaştıır. Özellikle NSAI ilaçlar, bazı antimikrobiyal ilaçlar (Aminoglikozidler,
Amfoterisin B, Vankomisin vb.) ve ACE inhibitörleri gibi nefrotoksik ilaçların kullanımına bu hastalarda dikkat etmek gerekir $(3,10,20,30,38)$. Bizim hastalarımızda nefrotoksik olan ilaçların kullanılmamasına özellikle dikkat edildi. Kullanılmakta olan ilaçlar ise uygun alternatifleri ile değiştirildi.

Renal yetmezlik riski olan hastalarda KM kullanımı ile artan böbrek fonksiyon değerleri için ekstrakorporyal dolaşım ile filtrasyon uygulanabilecek bir yöntemdir. Yapılan çalışmalarda CIN önlenmesinde RRT uygulanmasının, yalnızca prehidrasyon yapılan hastalardan daha etkin şekilde CIN gelişme olasılığını azalttığı gösterilmiştir $(2,35)$. Geriye dönük şekilde hasta verilerini değerlendirerek yaptığımız çalışmamızda, hasta sayımızın az olması, hastaların KM'ye maruz kalma öncesi kreatinin klirenslerinin değerlendirilmemesi, uygulanan koruyucu yöntemlerinin belirli bir standart çerçevesinde yapılmaması ve daha önceki çalışmalarla da benzer olarak serum kreatinin seviyelerinin başka nedenlerden yükselmesinin ayırdının tam ve net olarak yapılamaması çalışmamızın kısıtlayıcı özellikleri olarak belirlendi.

\section{Sonuç}

Sonuç olarak $\mathrm{CIN}$, hastane maliyeti ve hasta morbidite ve mortalitesine olan etkileri dolayısıyla önemli, önlenebilir ve geri döndürülebilir bir durumdur. CIN gelişiminin önlenebilmesi için öncelikle farkındalık ön planda olmalıdır. Özellikle kronik böbrek hastaları ve diyabetik hastalar olmak üzere yüksek risk altında bulunan hastalarda, KM verilmesi gerekliliği durumlarında, ön hidrasyona, uygun farmakolojik desteğe, düşük toksik potansiyeli olan KM'lerin kullanılmasına ve eş zamanlı nefrotoksik ajanların kullanımamasına dikkat edilmelidir. Çalışmamızda, yoğun bakımda takip edilmekte olan hastaların rutin izlenen parametrelerinden olan arteriyel oksijen basıncının düşük olması CIN gelişimi için bağımsız risk faktörü olarak belirlendi. Hastaların oksijenasyonlarının düzeltilmesi hem kolay, hem pratik ve çok basit manevralarla artırlabilecek bir parametredir. Sadece inspiratuvar oksijen fraksiyonunun artııımasıyla dahi sağlanabilir. Çalışmamızın sonucunda, böylesi önemli bir problemin çözümü için oksijenasyonun düzeltilmesine yönelik alınacak tedbirlerle yoğun bakım hastalarında CIN gelişim riskini azaltabilmenin mümkün olabileceğini vurgulamak istedik.

\section{Kaynaklar}

1. Laville M, Juillard L. Contrast-induced acute kidney injury: how should at-risk patients be identified and managed? J Nephrol 2010;23:387-98.

2. Reddan D, Laville M, Garovic VD. Contrast-induced nephropathy and its prevention: What do we really know from evidence-based findings? J Nephrol 2009;22:333-51. 
3. Bentley ML, Corwin HL, Dasta J. Drug-induced acute kidney injury in the critically ill adult: recognition and prevention strategies. Crit Care Med 2010;38(6 Suppl):S169-74.

4. Hoste EA, De Waele JJ, Gevaert SA, Uchino S, Kellum JA. Sodium bicarbonate for prevention of contrast-induced acute kidney injury: a systematic review and meta-analysis. Nephrol Dial Transplant 2010;25:747-58.

5. Samimagham HR, Kheirkhah S, Haghighi A, Najmi Z. Acute kidney injury in intensive care unit: incidence, risk factors and mortality rate. Saudi J Kidney Dis Transpl 2011;22:464-70.

6. Wirta O. [Acute renal failure]. Duodecim 2011;127:549-57.

7. Ellis $\mathrm{JH}$, Cohan $\mathrm{RH}$. Reducing the risk of contrast-induced nephropathy: a perspective on the controversies. AJR Am J Roentgenol 2009:192:1544-9.

8. Gerber Y, Rihal CS, Sundt TM 3rd, Killian JM, Weston SA, Therneau TM, et al. Coronary revascularization in the community. A population-based study, 1990 to 2004. J Am Coll Cardiol 2007; 50:1223-9

9. Toms AP, Cash CJ, Linton SJ, Dixon AK. Requests for body computed tomography: increasing workload, increasing indications and increasing age. Eur Radiol 2001;11:2633-7.

10. Chronopoulos A, Cruz DN, Ronco C. Hospital-acquired acute kidney injury in the elderly. Nat Rev Nephrol 2010;6:141-9.

11. Katzberg RW, Haller C. Contrast-induced nephrotoxicity: clinical landscape. Kidney Int Suppl 2006:S3-7.

12. Manske CL, Sprafka JM, Strony JT, Wang Y. Contrast nephropathy in azotemic diabetic patients undergoing coronary angiography. Am J Med 1990;89:615-20.

13. McCullough PA, Wolyn R, Rocher LL, Levin RN, O'Neill WW. Acute renal failure after coronary intervention: incidence, risk factors, and relationship to mortality. Am J Med 1997;103:368-75.

14. Morcos SK, Thomsen HS, Webb JA. Contrast-media-induced nephrotoxicity: a consensus report. Contrast Media Safety Committee, European Society of Urogenital Radiology (ESUR). Eur Radiol 1999:9:1602-13.

15. Rihal CS, Textor SC, Grill DE, Berger PB, Ting HH, Best PJ, et al. Incidence and prognostic importance of acute renal failure after percutaneous coronary intervention. Circulation 2002;105:2259-64.

16. Paraskevas KI, Giannoukas AD, Kotsikoris I, Mikhailidis DP. Contrast-induced nephropathy and the vascular patient. Angiology 2010;61:721-3.

17. Perazella MA. Current status of gadolinium toxicity in patients with kidney disease. Clin J Am Soc Nephrol 2009;4:461-9.

18. Haveman JW, Gansevoort RT, Bongaerts AH, Nijsten MW. Low incidence of nephropathy in surgical ICU patients receiving intravenous contrast: a retrospective analysis. Intensive Care Med 2006;32:1199-205.

19. Solomon R. Preventing contrast-induced nephropathy: problems, challenges and future directions. BMC Med 2009;7:24.

20. Cronin RE. Contrast-induced nephropathy: pathogenesis and prevention. Pediatr Nephrol 2010;25:191-204.

21. Solomon R, Dauerman HL. Contrast-induced acute kidney injury. Circulation 2010;122:2451-5.
22. Kagan A, Sheikh-Hamad D. Contrast-induced kidney injury: focus on modifiable risk factors and prophylactic strategies. Clin Cardiol 2010;33:62-6.

23. Heyman SN, Rosen S, Khamaisi M, Idee JM, Rosenberger C. Reactive oxygen species and the pathogenesis of radiocontrastinduced nephropathy. Invest Radiol 2010;45:188-95.

24. Heyman SN, Rosen S, Rosenberger C. Renal parenchymal hypoxia, hypoxia adaptation, and the pathogenesis of radiocontrast nephropathy. Clin J Am Soc Nephrol 2008;3:288-96.

25. Brezis M, Rosen S. Hypoxia of the renal medulla--its implications for disease. N Engl J Med 1995;332:647-55.

26. Heyman SN, Rosen S, Rosenberger C. Hypoxia-inducible factors and the prevention of acute organ injury. Crit Care 2011:15:209.

27. Hofmann L, Simon-Zoula S, Nowak A, Giger A, Vock P, Boesch $C$, et al. BOLD-MRI for the assessment of renal oxygenation in humans: acute effect of nephrotoxic xenobiotics. Kidney Int 2006;70:144-50.

28. Caruso M, Balasus F, Incalcaterra E, Ruggieri A, Evola S, Fattouch K, et al. Contrast-induced nephropathy after percutaneous coronary intervention in simple lesions: risk factors and incidence are affected by the definition utilized. Intern Med 2011;50:983-9.

29. Caixeta A, Mehran R. Evidence-based management of patients undergoing $\mathrm{PCl}$ : contrast-induced acute kidney injury. Catheter Cardiovasc Interv 2010;75 Suppl 1:S15-20.

30. Nunag $M$, Brogan $M$, Garrick R. Mitigating contrast-induced acute kidney injury associated with cardiac catheterization. Cardiol Rev 2009;17:263-9

31. ten Dam MA, Wetzels JF. Toxicity of contrast media: an update. Neth J Med 2008;66:416-22.

32. McCullough PA. Contrast-induced acute kidney injury. J Am Coll Cardiol 2008:51:1419-28.

33. Huber W, Jeschke B, Page M, Weiss W, Salmhofer $H$, Schweigart $U$, et al. Reduced incidence of radiocontrast-induced nephropathy in ICU patients under theophylline prophylaxis: a prospective comparison to series of patients at similar risk. Intensive Care Med 2001;27:1200-9.

34. Morcos SK. Contrast-induced nephropathy: are there differences between low osmolar and iso-osmolar iodinated contrast media? Clin Radiol 2009;64:468-72.

35. Sterling KA, Tehrani T, Rudnick MR. Clinical significance and preventive strategies for contrast-induced nephropathy. Curr Opin Nephrol Hypertens 2008;17:616-23.

36. Brown JR, Block CA, Malenka DJ, O'Connor GT, Schoolwerth AC, Thompson CA. Sodium bicarbonate plus $\mathrm{N}$-acetylcysteine prophylaxis: a meta-analysis. JACC Cardiovasc Interv 2009;2:1116-24.

37. Millea PJ. N-acetylcysteine: multiple clinical applications. Am Fam Physician 2009;80:265-9.

38. Mautone A, Brown JR. Contrast-induced nephropathy in patients undergoing elective and urgent procedures. J Interv Cardiol 2010;23:78-85. 